\title{
Assessment of Solid Waste Management Techniques in Maitama, Abuja, Nigeria
}

\author{
Freedom G. Joseph ${ }^{1}$, Joseph O. Folorunsho², Yakubu O. Yusuf ${ }^{1 *}$, Emmanuel I. Aruya ${ }^{1}$ \\ ${ }^{1}$ Department of Geography and Environmental Management, Ahmadu Bello University, Zaria 810006, Nigeria \\ ${ }^{2}$ Department of Geography, Federal University, Lokoja 260001, Nigeria
}

Corresponding Author Email: yyobadaki@gmail.com

https://doi.org/10.18280/ijsdp.150213

Received: 27 December 2018

Accepted: 21 August 2019

\section{Keywords:}

Abuja, Maitama, municipal solid waste, solid waste management

\begin{abstract}
Municipal solid waste management has emerged as one of the greatest challenges facing environmental protection agencies in developing countries. This study assessed the current solid waste management practices, problems and management in Maitama District, Abuja. The objectives of the study were to identify the structure of solid waste management and the sustainability of the process from generation to disposal. The research made use of structured questionnaires which were administered to residents of Maitama District, Abuja. The study revealed that women are more involved than men in the management of the heterogeneous waste in the study area. Although respondents recommended the services of waste collectors as $98 \%$ of them adjudged their services as satisfactory. There is still the problem of poor attitude to payment by residents of the area. The study therefore recommends that there should be more effective involvement of the private sector and greater integration of the informal sector, composting of biodegradable wastes and increased waste recycling and resource recovery can be areas for further development and better means of collection of waste charges should be developed in the study area.
\end{abstract}

\section{INTRODUCTION}

Human society makes a living by extracting environmental resources for food, shelter, and clothing, using tools it conceives, fabricates and develops over time. This ingenuity at making tools perfects its power to obtain and utilize the available resources sometimes with impunity. Such technological sophistication termed civilization facilitates faster acquisition and utilization of environmental resources. The consumption of these resources tends to generate waste or unwanted materials that must be discarded [1].

Wastes are generally classified into solid, liquid and gaseous [2]. Barry and Horton [3] see solid waste as unwanted and undesirable materials which originated from industrial and mining projects, agricultural and livestock activities, residential, commercial and municipal uses. Similarly, solid waste refers to any non-gaseous or liquid material that is discarded because it has no further use to the owner. This concept embraces all unwanted by- products dumped at any given place within an environment $[4,5]$. The United States Solid Waste Act (1965) defined solid waste as garbage, refuse, and material generated from commercial and agricultural operations as well as from community activities. According to Nigeria Federal Environmental protection Agency (1997), solid waste also refers to solid or semi-solid materials, resulting from human and animals' activities that are useless, unwanted or hazardous [6].

Municipal solid waste (MSW) is defined to include refuse from households, non-hazardous solid waste from industrial, commercial and institutional establishments (including hospitals), market waste, yard waste, and street sweepings. Municipal solid waste management (MSWM) refers to the collection, transfer, treatment, recycling, resources recovery and disposal of solid waste in urban areas. The goals of municipal solid waste management are to promote the quality of the urban environment, generate employment and income, and protect environmental health and support the efficiency and productivity of the economy [2].

Human society at every stage of civilization generates wastes. However, the rate of generation and methods of disposal varies from one nation to another depending on the level of their technological development. One of the challenges of the 21 st century is how to achieve cost-effective and environmentally sound strategies to deal with the global solid waste crisis confronting humanity in both developed and developing countries. Srinivas [7] reported that at least $60 \%$ of the countries that submitted the national report to the United Nations in advance of the 1992 UN Earth Summit said that solid waste disposal was among their biggest environmental concern, while the United Nation Centre for Human Settlement [8] report that only about $50-55 \%$ of all waste generated in large cities are collected by municipal authorities.

The sustainable management of solid waste aims at global environmental quality, which is a pre-requisite for a rise in per capita welfare over a period of time [9]. Efficient management of waste is a global concern requiring extensive research and development works towards exploring newer application for a sustainable and environmentally sound management [10]. The problem of waste management is a primordial and present issue in developing countries in Africa, particularly Nigeria. This is because her population has been on the increase, hence her generation of waste is also on the increase. Municipal solid waste management problems in Nigeria cut across concerns for human health, air, water, and land pollution among others. 
The analysis of the key problem affecting the efficient management of municipal waste is critical for evolving a workable solution in an emerging economy like Nigeria. The transformation of the existing trends in municipal solid waste management is necessary for ensuring sustainable environments and other objectives [11].

Municipal Solid Waste Management (MSWM) is a globally challenging issue especially in developing countries, due to its adverse environmental effects [12-14]. Solid waste management has emerged as one of the greatest challenges facing federal state and local government environmental protection agencies in Nigeria. The volume of solid waste being generated continues to increase at a faster rate than the ability of the agencies to improve on the financial and technical resources needed to parallel this growth. Solid waste management in Nigeria is characterized by inefficient collection methods, insufficient coverage of the collection system and improper disposal of solid waste [15].

According to Srinivas [7], one of the most pressing problems facing major urban areas in the developing countries at present is disposal of huge quantities of solid wastes, which accumulate in their cities as a by-product of modernization. This is also in line with [16] where it was observed that the leading industrial countries in the world have realized that continued waste generation cannot be offset by improved land filling techniques, but that alternative policies, practices and technologically advanced disposal methods need to be developed and implemented.

A research on the evaluation of solid waste management policy in Benin, by Dauda and Osita [17] discovered that Solid waste disposal constitutes a nuisance and creates a breeding ground for pests and diseases in Benin metropolis. The study also recommended that awareness campaign, payment of bonus for well sorted out solid wastes and technically desirable managed dump sites should be the main strategies of environmental solid waste policy in Benin City. Unfortunately, all aspects of man's productive activities virtually involve wastes generation [18-20].

Solid waste management in the Federal Capital territory, Abuja is characterized by inefficient collection methods, insufficient coverage of the collection system and improper disposal. The quantity of solid waste generated in the FCT is higher than in most cities in Nigeria [21]. Although the FCT has an existing structure on MSWM in terms of composition, density, political, and economic framework, waste amount, access to waste for collection, awareness and attitude one still finds wastes littered along the major streets in Maitama District. It is against this background that this study intends to fill the knowledge gap by examining the coordination of the solid waste in the district and examining the sustainability of the process of solid waste management from generation to disposal.

\section{THE STUDY AREA}

Abuja, the Federal Capital Territory (FCT), lies between latitude $9^{\circ} 4^{\prime}$ North of the equator and longitude $7^{\circ} 29^{\prime}$ East of the Greenwich Meridian (Figure 1). It is a planned city in the centre of the country bordered to the north by Kaduna state, to the east by Nassarawa state, to the south-west by Kogi state and to the west by Niger state. The area is considered the most ideal and conducive for human habitation and settlement. The FCT is rich in infrastructure such as expanding road network, drainage and sewage systems, pipe borne water, electricity, and communication networks. Due to its central location and accessibility, people from all parts of the country crowd into the city in search of better living [22]. Abuja under Koppen climate classification features a tropical wet and dry climate. The FCT experiences three weather conditions annually. This includes a warm, humid rainy season and a blistering dry season. In between the two, there is a brief interlude of harmattan (northeast trade wind) with the main feature of dust haze, intensified coldness and dryness [23].

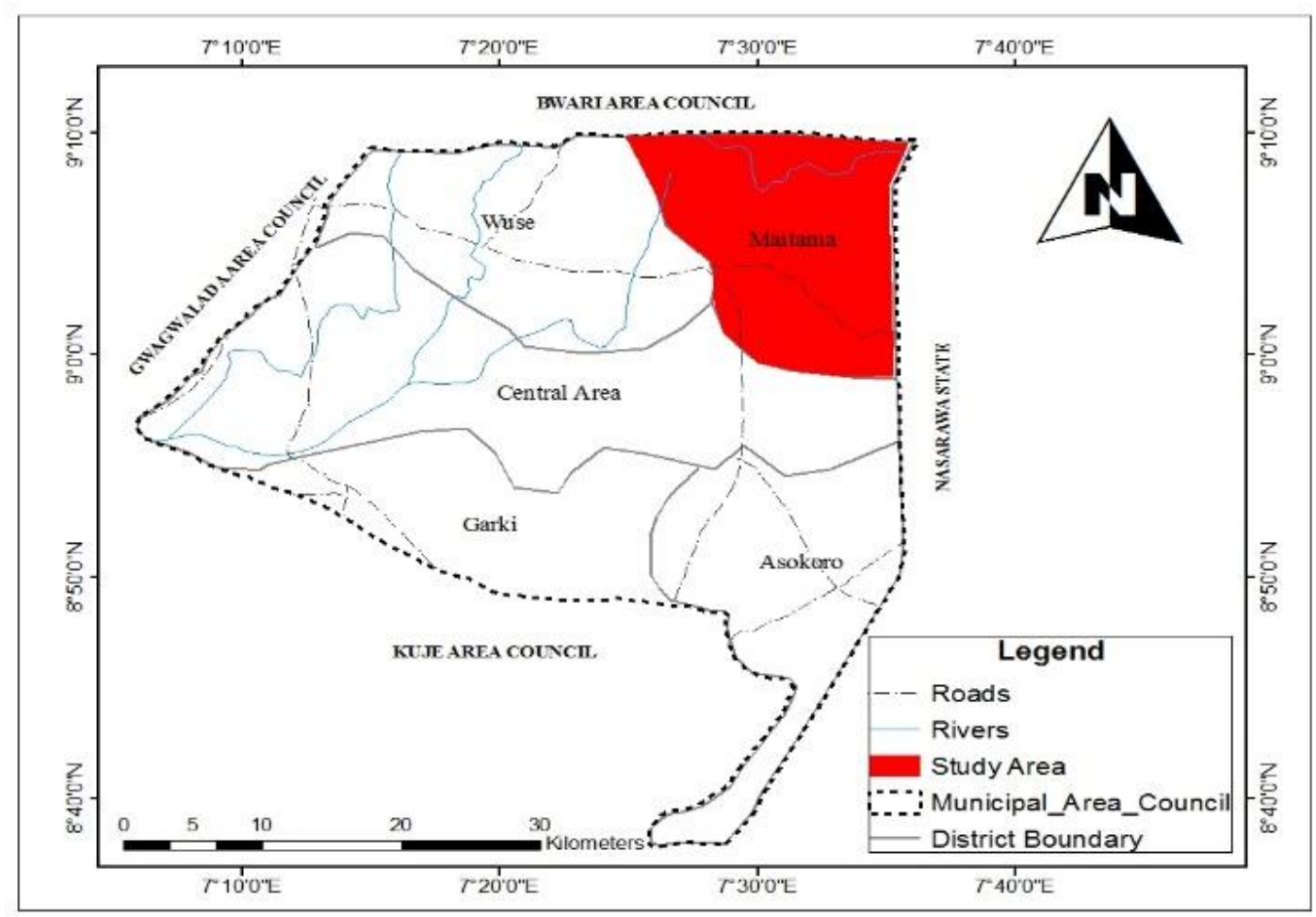

Figure 1. Abuja municipal council showing study area (Source: Modified from the Administrative Map of FCT) 


\section{METHODOLOGY}

The study employed mainly primary source of data which was derived from a structured questionnaire which was administered to residents of Maitama District of the FCT, Abuja. Random sampling technique was used in administering the questionnaire. A total respondent of 380 was used in this study. The main streets in the study area were used for this study which are, Gana, Osuma, Bobo, Pope John Paul II, Osse, Omega, Yedseram, Limpopo, Komoe, Owena, Cuito, Katsina Ala, Ruvuma, Gurara, Seiviri, Rio Negro, Yobe Close, Ganges, Panama, Rhine, Osun Crescent, Baltic Crescent, Nun, Pep, Nolin Lake, Danube, River Niger, Danube Close, River Nahan, Nike lake, Nilaka, Oguta Lake, Tangayika, Rima, Amazon, Thames, Salween Mississippi and Oyi River.

In order to achieve the aim of this study, the questionnaire provided the following data; type and composition of municipal solid waste, method of solid waste collection, agency responsible for waste collection, cost and frequency of solid waste collection, solid waste disposal and management methods and challenges of management of domestic solid waste

The sample size was determined using the Krejcie and Morgan (1970) method of determination of population size. The collected data were analyzed using tables and charts. All statistical analyses were carried out using SPSS version 20 and Microsoft Excel 2013.

\section{RESULTS AND DISCUSSIONS}

\subsection{Socio-demographic characteristics of respondents}

Table 1 reveals that $64.7 \%$ of the respondents are female whereas the male constitutes $35.3 \%$. This implies that female mostly engage in domestic waste management when compared with their male counterparts. The reason for this is the cultural belief in most African societies that females are responsible for the upkeep of the homes.

Table 1. Socio-demographic characteristics of respondents in the study area

\begin{tabular}{ccc}
\hline Sex & Frequency & Percentage \\
\hline Male & 134 & 35.3 \\
Female & 246 & 64.7 \\
Total & $\mathbf{3 8 0}$ & $\mathbf{1 0 0}$ \\
\hline Age & Frequency & Percentage \\
\hline Less than 20 years & 7 & 1.8 \\
21-30 years & 87 & 22.9 \\
31-40 years & 121 & 31.8 \\
41 and above & 165 & 43.5 \\
Total & $\mathbf{3 8 0}$ & $\mathbf{1 0 0}$ \\
\hline Marital Status & Frequency & Percentage \\
\hline Married & 302 & 79.5 \\
Single & 71 & 18.7 \\
Separated & 7 & 1.8 \\
Total & $\mathbf{3 8 0}$ & $\mathbf{1 0 0}$ \\
\hline Household Size & Frequency & Percentage \\
\hline $1-3$ & 112 & 29.5 \\
$4-6$ & 198 & 52.1 \\
$7-10$ & 70 & 18.4 \\
Total & $\mathbf{3 8 0}$ & $\mathbf{1 0 0}$ \\
\hline
\end{tabular}

Source: Field survey 2016
Age is an important socio-demographic attribute because adults tend to participate in solid waste management when compared with children. Table 1 reveals that $43.5 \%$ of the respondents are between the ages of 41 and above while $31.8 \%$ are between the ages of 31-40 indicating that most of the respondents are adults.

The marital status of respondents as revealed by Table 1 shows that $79.5 \%$ are married, $18.7 \%$ are single while $1.8 \%$ are separated. This means that most of the respondents have a family to cater for. This can also influence the amount of waste to be generated.

Indeed, as revealed by Table $1,52.1 \%$ of the respondents have a population of about 4-6 members in their houses, $29.5 \%$ have a population of $1-3$ people while $18.4 \%$ have a population of 7-10 people. The implication of this result is that large volume of waste will be generated because as portrayed by Solano, Iriarte, Ciria and Negro [24], the larger the household sizes, the higher the volume of waste generated.

\subsection{Socio-economic characteristics of respondents}

Occupation, educational status and income are the major socio-economic indices assessed. Table 2 reveals that $51.6 \%$ of the respondents are civil servants while $4.5 \%$ are traders. It is expected that the respondents should have positive attitudes towards participating in domestic waste management.

The educational status of respondent reveals that most of the respondents $(91.3 \%)$ have at least tertiary education while the remaining $8.7 \%$ have secondary school certificate. This indicates that all respondents can read and interpret the questionnaire and are capable of providing relevant answers.

Also, there exist a close relationship between educational status and domestic waste management as in most cases educated persons tend to maintain healthier environment when compared with their uneducated counterparts.

Table 2. Socio-economic characteristics of respondents in the study area

\begin{tabular}{ccc}
\hline Occupation & Frequency & Percentage \\
\hline Civil servant & 196 & 51.6 \\
Trader & 17 & 4.5 \\
Self employed & 114 & 30 \\
Unemployed & 19 & 5 \\
Others & 34 & 8.9 \\
Total & $\mathbf{3 8 0}$ & $\mathbf{1 0 0}$ \\
\hline Educational Status & Frequency & Percentage \\
\hline Secondary school & 33 & 8.7 \\
Tertiary & 347 & 91.3 \\
Total & $\mathbf{3 8 0}$ & $\mathbf{1 0 0}$ \\
\hline Monthly Income (A) & Frequency & Percentage \\
\hline 5,001-10,000 & 14 & 3.7 \\
10,001-15,000 & 20 & 5.3 \\
20,000 above & 346 & 91 \\
Total & $\mathbf{3 8 0}$ & $\mathbf{1 0 0}$ \\
\hline Source: Field survey 2016 & &
\end{tabular}

Income is a major determinant of standard of living given that it informs the method people use to manage their household waste. As revealed in Table 2, about $91 \%$ of the respondents earn $\$ 20,000$ and above, $5.3 \%$ earn between $\$ 10,000$ to $\$ 15,000$ while $3.7 \%$ earn $\$ 5,000$ to $\$ 10,000$. The higher income earned by most of the respondents is most probably because of the educational status of the respondents. 


\subsection{Composition of MSW and disposal methods in the study area}

On-site waste separation and measurements was done at selected households. This involved sorting and weighing all municipal solid waste. The total volume and percentage distribution of MSW is shown in Table 3. The main components are food residues, plastics, paper, glass bottles and metals. Table 3 reveals that the solid waste in Maitama District has a heterogeneous composition since $90.6 \%$ of the waste generated is a complex mix comprising of both degradable and non-degradable materials, and it is collected without sorting. The bulk of the non-degradable waste is potentially recyclable materials, while the degradable materials could be fermented to form methane. Plastics mainly come from water and fruit juice bags and containers.

Table 3. Waste type generated after sorting

\begin{tabular}{ccc}
\hline Waste Type & $\begin{array}{c}\text { Approximate } \\
\text { Volume }(\mathbf{K g})\end{array}$ & $\begin{array}{c}\text { Percentage of Total } \\
\text { Waste after sorting }\end{array}$ \\
\hline Garbage only & 2100 & 0.9 \\
Plastic only & 4850 & 2.2 \\
Bottle only & 10245 & 4.6 \\
Food Residue & 2147 & 1.0 \\
Metals & 1562 & 0.7 \\
All of the above & 201369 & 90.6 \\
\hline Total & $\mathbf{2 2 2 , 2 7 3}$ & $\mathbf{1 0 0}$ \\
\hline
\end{tabular}

Source: Field survey 2016.

Table 4 shows the disposal methods of generated wastes in the study area. Illegal disposal is common in the study area Piles of solid wastes are often found along roads (Figure 2a), underneath bridges, in culverts and drainage channels and in other open spaces. From Table 4, it can be clearly seen that $52.6 \%$ agree that their wastes are collected by waste managers (Figure 2b), 24.5\% still practice indiscriminate dumping, $15.5 \%$ burn their waste, $4.2 \%$ take the waste to designated points for collection while the remaining $3.2 \%$ bury their waste.

Table 4. Disposal methods

\begin{tabular}{ccc}
\hline Disposal Method & Frequency by Number & Percentage \\
\hline $\begin{array}{c}\text { Burrowed pit/ } \\
\text { backyard }\end{array}$ & 12 & 3.2 \\
$\begin{array}{c}\text { Burn them } \\
\text { Indiscriminate } \\
\quad \text { Dumping }\end{array}$ & 59 & 15.5 \\
$\begin{array}{c}\text { Collected by waste } \\
\text { manager }\end{array}$ & 93 & 24.5 \\
$\begin{array}{c}\text { Taken to designated } \\
\text { points }\end{array}$ & 200 & 52.6 \\
\hline Total & 16 & 4.2 \\
\hline
\end{tabular}

Source: Field survey 2016

The result from Table 4 reveals a multi-faceted but organized system of waste disposal in the study area as against land filling, incineration and composting methods of solid waste disposal and management as identified in the study of Babayemi and Dauda [25]. Figure 2a and Figure 2b shows indiscriminate dumping and collection of wastes by waste managers respectively.

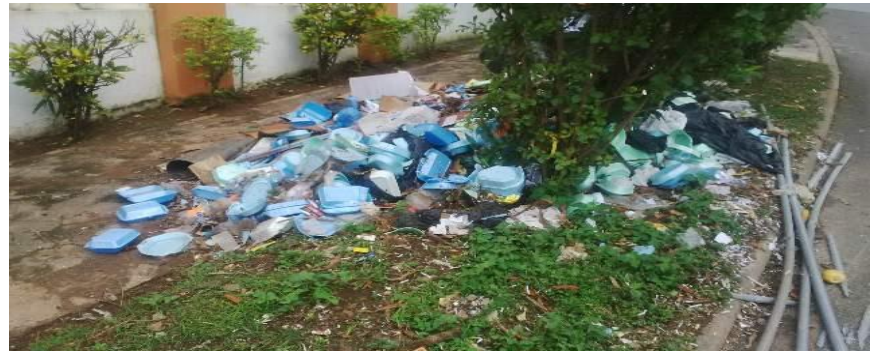

a. Indiscriminate dumping of wastes (Source: Field survey 2016)

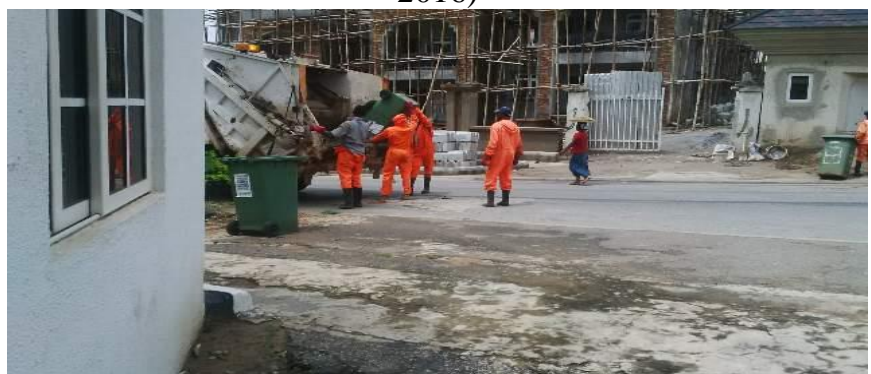

b. Collection of wastes by waste managers (Source: Field survey 2016)

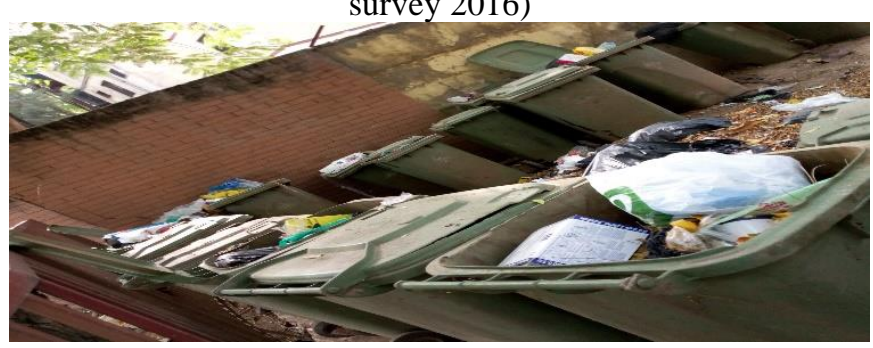

c. Government authority situating waste bins for waste collection (Source: Field survey 2016)

Figure 2. Solid waste management in Maitama, Abuja

\subsection{The management of solid waste in the study area}

Collection and transportation are a major cost in the waste management process. There are 12 private companies currently operating that collect waste. Private firms collect house-to-house, typically between one and three times a week, depending on the availability and condition of their vehicles. Collection of kerbside deposited waste tends to be quite irregular. Informal sector collection workers also operate house-to-house collection services; they often separate out recyclable materials and dump unwanted degradable waste around the area. As a result, such informal collectors are officially banned from certain districts, and their carts are regularly impounded by the authorities. Collection and transportation of waste is both labour and capital intensive. It has been estimated that waste transportation, including labour and machinery, accounts for between $70 \%$ and $80 \%$ of the total cost of solid waste management in Nigeria [26, 27]. Therefore, Table 5 confirms that $49.2 \%$ of the respondents reported that government authority collects their solid domestic waste (Plate 3), private waste managers account for $44.7 \%$, informal sector, $5 \%$ and scavengers with $1.1 \%$.

The result above reveals that public sector is greatly involved in MSW management in the study area. It therefore contradicts the results of Dauda and Osita [16] in Benin where the researchers observed that informal sector was the predominant medium of waste collection, thereby leaving in its wake several environmental and health challenges. 
Table 5. Waste collection medium

\begin{tabular}{ccc}
\hline Collection Medium & Frequency & Percentage \\
\hline Government authority & 187 & 49.2 \\
Private waste managers & 170 & 44.7 \\
Scavengers & 4 & 1.1 \\
Informal sector & 19 & 5 \\
\hline Total & $\mathbf{3 8 0}$ & $\mathbf{1 0 0}$ \\
\hline
\end{tabular}

Source: Field survey 2016

Figure $2 \mathrm{c}$, confirms the role of government authority in situating waste bins close to residential areas and at designated collection points in order to effectively collect waste. Also, the frequency of Municipal solid waste collection in the study area is shown in Table 6.

Table 6. Frequency of waste collection

\begin{tabular}{ccc}
\hline Frequency of Collection & Frequency & Percentage \\
\hline Weekly & 12 & 3.2 \\
Monthly & 325 & 85.5 \\
Others & 11 & 2.9 \\
No entry & 32 & 8.4 \\
\hline Total & $\mathbf{3 8 0}$ & $\mathbf{1 0 0}$ \\
\hline
\end{tabular}

Source: Field survey 2016

Indeed, as revealed by Table 6 , most $(85.5 \%)$ of the respondents in the study area agree that their waste collection is monthly as outlined by Gaza [21], the longer the frequency of waste collection the greater the probability of seeing overflowing waste bins in the study area and its concomitant effects in terms of health and environmental sustainability.

The distance of households from collection sites can influence their choice of disposal techniques [25]. This corroborates the work of Agunwamba [14] where the researcher revealed that as long as distances to collection sites are far, indiscriminate dumping of waste is inevitable. Therefore Table 7 clearly shows that most collection sites are within the range of 500metres which means that most collection sites are within walking distances from households.

Table 7. Distance of collection sites to respondents' home

\begin{tabular}{ccc}
\hline Distance & Frequency & Percentage \\
\hline Less than $500 \mathrm{~m}$ & 359 & 94.5 \\
$500 \mathrm{~m}-1 \mathrm{~km}$ & 6 & 1.6 \\
Above $1 \mathrm{~km}$ & 10 & 2.6 \\
No entry & 5 & 1.3 \\
\hline Total & $\mathbf{3 8 0}$ & $\mathbf{1 0 0}$ \\
\hline
\end{tabular}

Source: Field survey 2016

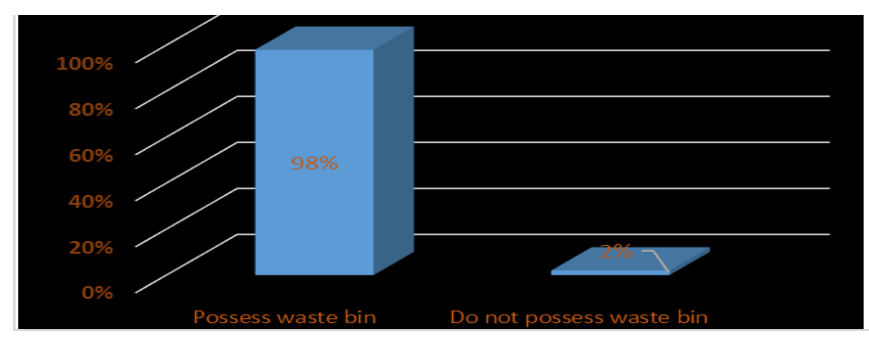

Figure 3. Possession of standard waste bin (Source: Field survey 2016)

Since Oluwande [25] revealed that a key aspect of effective waste management is proper waste storage on the premises where the waste is generated, Figure 3 seeks to assess the availability of standard waste bins in the households of respondents. Indeed, as revealed by Figure 3, most of the respondents have standard waste bin in the study area which suggests convenient method of waste disposal in the study area.

\subsection{The effectiveness of municipal solid waste management in the study area}

\subsubsection{Cost of waste disposal}

Funding and affordability remain among the major constraints and challenges. An element of specific user charging will be needed to supplement municipal and national taxes. The current exchange rate is about $\$ 360$ to $\$ 1$ (USD). From Table 8 , it can be clearly seen that $44.5 \%$ of the respondents pay about $\$ 600$ weekly, 23.9\% pay about $\$ 300$ weekly, while $20 \%$ pay above $\$ 700$ weekly.

Table 8. Cost for the service

\begin{tabular}{ccc}
\hline Cost per Annum (\$) & Frequency & Percentage \\
\hline $10,001-15,000$ & 91 & 23.9 \\
$25,001-30,000$ & 169 & 44.5 \\
Above 35,000 & 76 & 20 \\
No Response & 44 & 11.6 \\
\hline Total & $\mathbf{3 8 0}$ & $\mathbf{1 0 0}$ \\
\hline
\end{tabular}

Source: Field survey 2016

Considering the income level of respondents in Table 2 above, most respondents should be comfortable paying the charges for waste disposal.

However, the perception assessment of the charges for waste collection and disposal as shown in Table 9 reveals that $73.4 \%$ and $7.1 \%$ agree that the fee is moderate and cheap respectively while $8.9 \%$ said the charges are quite expensive

Table 9. Payment rate

\begin{tabular}{ccc}
\hline Payment Rate & Frequency & Percentage \\
\hline Cheap & 27 & 7.1 \\
Moderate & 279 & 73.4 \\
Expensive & 24 & 6.3 \\
Very expensive & 10 & 2.6 \\
No entry & 40 & 10.6 \\
\hline Total & $\mathbf{3 8 0}$ & $\mathbf{1 0 0}$ \\
Source: Field survey 2016 & &
\end{tabular}

\subsubsection{Assessment of solid waste management service}

The assessment of services rendered by solid waste managers in the study area as shown in Figure 4 reveals that $56 \%$ consider their services as good or very good while $42 \%$ consider the services as satisfactory. This might be connected with the use of private waste managers whose promptness in collection and disposal of waste cannot be compared with public managers.

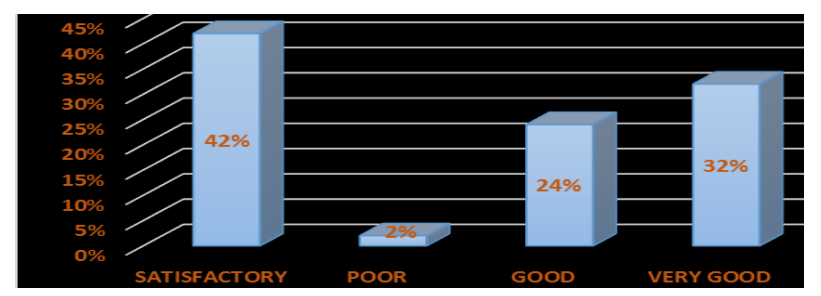

Figure 4. Assessment of solid waste management service Source: Field survey 2016 
This result agrees with Wali [28] that $64.3 \%$ severity index of the public was satisfied with the current solid waste management system.

\subsection{Problems of solid waste management in the study area}

Poor funding is one of the main reasons for poor collection and disposal of refuse. Lack of funds has forced most environmental protection agencies in the country to hire vehicles and maintain few staff on a permanent basis [25]. However, Table 10 assesses constraints to effective MSWM in the study area. As revealed by Table 10, attitude of residents towards payment is the major reason for inefficient waste disposal in the study area.

Table 10. Problems of solid waste management

\begin{tabular}{ccc}
\hline Problems & Frequency & Percentage \\
\hline Lack of waste facilities & 21 & 5.5 \\
Poor sanitary habits of the residents & 45 & 11.8 \\
Large population & 40 & 10.5 \\
Residents poor attitude towards & 251 & 66.2 \\
payment & 16 & 4.2 \\
Improper physical planning & 7 & 1.8 \\
High waste charges & $\mathbf{3 8 0}$ & $\mathbf{1 0 0}$ \\
\hline Total & & \\
\hline
\end{tabular}

Source: Field survey 2016

This corroborates with the work Agunwamba [14] where the researcher noted that public awareness and attitudes to waste can affect all stages in the solid waste management process as it has an impact on household waste storage, waste segregation, recycling, collection frequency, littering and flytipping, willingness to pay for waste management services, and the level and type of opposition to waste treatment and disposal facilities.

\section{CONCLUSION AND RECOMMENDATIONS}

\subsection{Conclusion}

This study revealed that the study area has structured systems designed to collect, transport and effectively dispose waste. However, despite this, residents' poor attitude towards payments and poor sanitary habits have greatly affected the sustainability of the structured systems

\subsection{Recommendations}

(1) There should be more effective involvement of the private sector and greater integration of the informal sector

(2) Since residents' attitude towards payments is poor, it is highly recommended that better means of collection of waste charges be developed in the study area.

\section{REFERENCES}

[1] Seadon, G.K. (2006). Intergrated waste management; looking beyond the solid waste horizon. Waste Management, 26(12): 1327-1336 https://doi.org/10.1016/j.wasman.2006.04.009
[2] Benz, G., John, S., Robert, M. (1999). Institutional and management approach to solid waste disposal in large metropolitan areas. Waste Management and Research, 4(9): 525-536. https://doi.org/10.1016/0734242X(91)90052-9

[3] Barry, B.T.L., Horton, F.E. (1974). Urban Environment Management. Practice. Hall Publication, New Jersey.

[4] Marx, T. (2004). International Environmental Overview of Major Issue. Congregational Research Service United State.

[5] Udanwu, C.J. (2007). Solid waste generation in nigerian urban centers. An Unpublished B.sc Project, Department of Geography, University of Nigeria, Nssuka.

[6] Doan, P. (1998). Institutionalizing household waste collection: urban environmental management in africa. Habitat International, 22(1): 27-39. https://doi.org/10.1016/S0197-3975(97)00020-9

[7] Srinivas, H. (2002). Urban Waste Management: Key Facts on Waste Issues. Global Development Research Centre.

[8] United Nation Centre for Human Settlement (UNCHS 2002). International Source Book on Human Settlement Allocation and Environmental Sustainability Technical Publication, USA.

[9] Ayininuola, G.M., Muibi, M.A. (2008). An engineering approach to solid waste collection system: Ibadan north as case study. Waste Management, 28(9): 168-177. https://doi.org/10.1016/j.wasman.2007.06.004

[10] Bari, Q.H., Hassan, K.M., Haque, M.E. (2012). Solid Waste Recycling in Rajshahi City of Bangladesh. Waste Management, 32(11): 2029-2036.

[11] Abila, B., Kantola, J. (2013). Municipal solid waste management problems in Nigeria: Evolving knowledge management solution. International Journal of Environmental, Ecological, Geological and Mining Engineering, 7(6): 169-174.

[12] Zamorano, M., Molerob, E., Grindlayb, A., Rodríguezc, M.L., Hurtadoa, A., Calvo, F.G. (2009). A planning scenario for the application of geographical information systems in municipal waste collection: A case of churriana de la Vega (Granada, Spain). Resources. Conservation and Recycling. 54(2), 123-133. https://doi.org/10.1016/j.resconrec.2009.07.001

[13] Jalil, A. (2010). Sustainable development in Malaysia: A case study on household waste management. Sustainable Development, 3(3): 91-102. https://doi.org/10.5539/jsd.v3n3p91

[14] Adekunle, I.M., Adebola, A.A., Aderonke, K.A., Pius, O.A., Toyin, A.A. (2011). Recycling of organic wastes through composting for land applications: A Nigerian experience. Waste Management Resources, 29(6): 58293. https://doi.org/10.1177/0734242X10387312

[15] Agunwamba, J.C., Egbuniwe. N., Ogwueleka T.C. (2003). Least cost management of solid waste collection. Journal of Solid Waste Technology and Management, 29(3): 154-167.

[16] Ezema, T.O. (2009). The problems of managing solid waste in a depressed economy. Journal of Sustainable Development, 5(2): 45-55.

[17] Dauda, M., Osita, O.O. (2003). Solid waste management and reuse in Benin Nigeria. 29th WEDC International Conference towards the Millennium Development Goal, Abuja.

[18] Scott, J. (1953). Health consideration involved in the 
treatment and disposal of waste from isolated dwellings. World Health Organization (WHO) Monograph Series. No. 18 Geneva 1953.

[19] Furedy, C., Alamgir, M. (1992). Street pickers in Calcutta slums. Environment and Urbanazation, 4(2): 6777.

[20] DiGregorio, M.R. (1994). Urban Harvest; recycling as a peasant industry in northern Vietnam; east-west centre occasional papers. Environmental Series, 17: 8-23.

[21] Peter, S., Karl, W., Jurg, C. (1996). Conceptual framework for municipal solid waste management in low-income countries. A Working Paper, 4(9): 20-26.

[22] Gaza, L.Z. (2008). Effect of Urban Residential Housing Demand on Land and Livelihood activities in the rural areas of the Federal Capital Territory, Abuja. Unpublished PhD Dissertation submitted to Department of Geography, Ahmadu Bello University, Zaria, p. 6.

[23] Chiegeonu, A.S. (2009). Abuja FCT. Nigeria: State by State.
[24] Solano, M.L., Iriarte, F., Ciria, P., Negro, M.J. (2001). Performance characteristics of three aeration systems in the composting of sheep manure and straw. Journal of Agricultural Engineering Resource, 79(3): 317-329.

[25] Babayemi, J.O., Dauda, K.T. (2009). Evaluation of solid waste generation, categories disposal options in developing countries: A case study of Nigeria. Journal of Applied Science and Environmental Management, 13(3): 83-88. http://dx.doi.org/10.4314/jasem.v13i3.55370

[26] Oluwande, P.A. (1984). Assessment of metropolitan solid waste management problems in China and Africa. In: Holmes, J.R. (Ed.), Managing Solid Waste in Developing Countries. J. Wiley, Chichester, UK.

[27] UDBN (Urban Development Bank of Nigeria). (1998). Solid Waste Sector Appraisal Report

[28] Wali, K.I. (2014). Investigation into the public perception towards the solid waste management system Adopted in Erbil City, Zanco. Journal of Pure and Applied Science, 26(1): 36-49. 